\title{
Goldratt's Theory Applied to the Problems Associated with the Mode of Transportation, Storage and Sale of Fresh Fruits \& Vegetables in Nigeria
}

\author{
Lloyd J. Taylor and Taiwo O. Esan \\ School of Business, University of Texas of the Permian Basin Odessa, TX, USA
}

\begin{abstract}
Current practices used in the cultivation, harvesting, handling, transportation of fresh fruits and vegetables in Nigeria have resulted in vast losses especially due to the seasonality and perishability of these produce, with the resulting situation being that there are times when there are excess produce, which are wasted in most cases due to the fact that the excess are not being processed or stored properly, and times of scarcity when people hardly have enough produce. It is obvious that there are a lot of inherent problems involved in the way and manner in which these produce are being handled. The purpose of this paper is to use Goldratt's Theory of Constraints and Thinking Process, which has been used in many cases, to improve performance and resolve problems in many business processes, to identify the core problem responsible for these losses and wastage with a view to generate useful information necessary to seek ways in which to improve the current situation and minimize the current losses being encountered which would be beneficial to the grower, traders, consumers and ultimately the Nigerian economy.
\end{abstract}

Keywords: Theory of Constraints, Thinking process, Current Reality Tree, Evaporating Cloud, Future Reality Tree, Fruits and vegetables Transportation, Storage of Fruits and vegetable and Sale of Fruits and vegetables.

\section{Introduction}

The Federal Republic of Nigeria is located in West Africa and is estimated to be the most populous country in Africa with an estimated population of $155,215,573$ inhabitants (July 2011 CIA World fact book.)

Geographically Nigeria is located between longitude $4^{\circ}$ and $14^{\circ} \mathrm{N}$ and latitude $2^{\circ}$ and $14^{\circ} \mathrm{E}$, making it a country with a tropical climate type where seasons are damp and very humid. The country has two broad vegetation types namely: forest and savannah. The relatively long rainy season, resulting in high annual rainfall above
$2000 \mathrm{~mm}$ in the southern part of the country ensures adequate supply of water which makes the land fertile and luxuriant for vegetation.

Indeed before the country's independence in 1960, Nigeria was self-sufficient in terms of food; however, with the discovery of oil, rural urban migration and emphasis on industry coupled with drastic population growth, Nigeria now imports most of its food.

With the rich soil and favorable climatic conditions, the country is able to produce diverse crops and produce. Indeed enormous quantities of fruits and vegetables are produced and staggering figures are

Copyright (C) 2012 Lloyd J. Taylor and Taiwo O. Esan. This is an open access article distributed under the Creative Commons Attribution License unported 3.0, which permits unrestricted use, distribution, and reproduction in any medium, provided that original work is properly cited. Contact author: Lloyd J. Taylor E-mail: taylor_l@utpb.edu 
sometimes given as estimated annual production. For example, figures like 3.8 million tons of onions, 6 million tons of tomatoes, 15 million tons of plantain and 35 million tons of citrus have been quoted as annual production levels for some fruits and vegetables, which are really large quantities of food crops (Oyeniran, 1988; Erinle, 1989). The production of bulk of the fresh tomato and pepper fruits in Nigeria especially Roma variety is in the Northern part of the country whereas the consumption and utilization is done all over the country. They are very important in the preparation of many of Nigerian staple and are either used fresh or processed into paste, puree, ketchup etc. (Idah, Ajisegiri \& Yisa, 2007).

Unfortunately, the current situation is that a large quantity of the produce are often lost in the post- harvest stages due to the mishandling, spoilage, pest infestation, use of obsolete farming practices, physiological breakdown due to natural ripening processes; environmental conditions such as heat, drought, improper postharvest sanitation, poor storage and packaging practices and mechanical damage during harvesting, handling and transportation. ((Jones, Holt \&Schoorl, 1991; Idah et. al., 2007).

\section{Review of Literature}

Fruits and vegetables are living things and carry out their physiological function of respiration by absorbing and releasing gases and other materials from and to their environment. (Idah et al., 2007) Most of the produce often has to be transported from where they are grown to the market over hundreds of kilometers of bad and poorly maintained road under unsatisfactory conditions such as high temperature, high humidity, improper storage etc. This tend to hasten the deterioration of the produce, a large amount is spoilt during post-harvest handling, transportation and storage.

Also because most of the farmers are small scale subsistent farmers they often lack the knowledge of the proper handling techniques or are unable to afford the expense of proper handling, storage, packaging, and transportation. The traders, retailers and wholesalers are also equally handicapped.

Transporting the produce from the village and farms where the produce is cultivated to the towns is the first hurdle. Rail transportation system is at best epileptic and therefore the produce have to be transported by road over hundreds of kilometers of often poorly maintained roads over a period of days in open trucks. A significant portion of the produce is therefore lost during the transportation process.

Often produce has to sit for days while waiting for trucks, which in most cases are open and sometimes dilapidated; often owned and/or operated by third party transporters. These trucks are sometimes not available resulting in harvested produce being kept in un-conducive conditions or the handlers resorting to the use of unconventional mode of transportation such as passenger buses in order to push the produce to market. Their attempt to get the produce to market as soon as possible can result in the produce being closely stacked together in order to "optimize the available space." This unfortunately results in compression, bruising and poor ventilation leading to mechanical damage and the onset of product rot.

An assessment carried out by Idah et al., (2007) at the Ipata market in Ilorin for example showed an average of $1041.67 \mathrm{~kg}$ or $13.89 \%$ of a $7,500 \mathrm{~kg}$ capacity lorry load of fresh tomato fruits were damaged during transportation which is quite significant, which in monetary value was reported to be about twenty thousand Naira (an equivalent of about 127.11 dollars) per trip.

Although losses are naturally expected and according to Food and Agriculture Organization of the United Nations (FAO) Assistant Director-General Agriculture Department, C.H Bonte - Friedheim " Both 
quantitative and qualitative food losses of extremely variable magnitude occur at all stages in the post-harvest system from harvesting, through handling, storage, processing and marketing to final delivery to the consumer" (FAO,1989). Postharvest losses of fruits and vegetables being experienced in Nigeria is of a great magnitude. It has been estimated that losses as high as about $40-50 \%$ of tomatoes and about $20-30 \%$ of bell and hot pepper are lost at post-harvest stage every year (Okhuoya, 1995). This ultimately translates to loss of income which is not good either for the economy nor for the people in the industry who after all the effort being put into growing the produce see a large percentage being wasted due to improper and obsolete practices.

Further due to the fact that modern technology and agricultural practices are not being implemented and due to the seasonality of the produce there are times where there is excess produce, which are in most cases lost due to lack of preservation techniques and lack of proper storage and transportation facilities. There are also times when the produce are scarce, however studies have shown that if the right practices are used, the length of availability can be stretched such that produce are available for a longer period leading to consistent availability of produce. For instance, use of particular type of seedlings, delaying ripening, harvesting, preservation of excess produce for future use, use of proper storage facilities etc.

Olayemi, Adegbola, Bamishaiye \& Daura (2010) observed and confirmed, based on their study, that the current farming system of tomatoes, bell pepper and hot pepper are inadequate. According to them, the farmers lack some fundamental knowledge and facts about post-harvest handling practices and young people are no longer interested in the farming industry, probably because they consider farming and trading of farm produce as a low level job and because of the lure of better paying white collar and blue collar jobs. Some other problems identified also included: lack of suitable packaging containers, farm structure and so on. They therefore made the following recommendations, some of which have also been incorporated as injections for the core problem:

- Provision of extension services on postharvest handling to the farmers by extension agent of Agriculture Development Programme (ADP) with relevant research inputs.

- Adoption of technologies of some research institutes that will benefit them.

- Provision of farm structures and materials relevant to post-harvest handling and their adoption.

- Encourage youths to farm by making resources available.

It is therefore essential to employ the best practices possible in order to combat these problems, look for ways to extend the produce life and to employ modern farming and preservation techniques which can be used to extend the life of the produce and prevent avoidable deterioration and wastage. (Hall,1968; Adeniyi, 1977; Agboola,1980).

\section{The Thinking Process and the Theory of Constraints}

During the 1980's, Goldratt [1992-b] wrote a book entitled The Goal. In this book, he conveys the story of a plant manager struggling to keep his plant afloat while searching for a way to improve the plant's performance. With the help of an old college professor, the manager learns how to improve the performance of his plant while also learning a method for resolving problems to the point of a win-win situation. Goldratt's Theory of Constraints (TOC) focuses on the efficiency of all the processes as a whole rather than the efficiency of any one single process. While the TOC was developed for manufacturing through 
Goldratt's Thinking Process, the Thinking Process system can be used to work through many other business processes and problems.

In Goldratt's TOC, a given group of processes will have a weakest link and the weakest link controls the entire systems production rate. In order to maximize the system production, the weakest link must be improved and all other links in the processes regulated to the speed of the weakest link. The weakest link is the constraint and all steps must be examined together to determine the constraint; the core problem for termination.

Since the constraint is not always obvious, Goldratt [1992-b] developed the Thinking Process. This is a series of steps used to locate the constraint (What to Change?), determine the solution (What to change to?) and how to implement the solution (How to make the change?). These steps are actually referred to as the Thinking Process. Goldratt's next book It's Not Luck [1994] describes the Thinking Process in much more detail.

\section{What to Change?}

If the symptoms of a core problem are undesirable effects (UDEs), then the undesirable effects are merely symptoms brought on by the core problem itself. This core problem needs to be determined and eliminated. The methodology employed in the search for a core problem is based on a cause and effect relationships. These cause and effect relationship are used to uncover the core problem associated with the UDEs. The core problem is also the weak link in the operation when it concerns obtaining the goal of the company.
By determining the true core problem in a situation, it is helpful to write the current state in a diagram format. This diagram shows a logical explanation of the situation. With practice and logical based common sense, the major UDEs can be interconnected through cause and effect relationships in a Current Reality Tree (CRT). Creating this tool leads to the process of determining "What to Change." Goldratt [1992-a] claims, the analytical method of a CRT is used in attempting to reveal the Archimedes point the identification of the root cause.

This analysis method also provides a tool to understand the existing nature of the cause. It does this by discussing and scrutinizing our basic intuitive sense, which exists in our environment. It is somewhat different from the management approach of correlation and classification. All past unsuccessful efforts to eliminate the undesirable effects failed to attack and eliminate the core problem. That's why the symptoms returned. In general, employees want to do a good job. They want to do what is best for the organization but don't always feel current procedures allow for core problem elimination.

\section{Undesirable Effects}

According to Goldratt [1994] the first step in the Thinking Process is to develop a list of at least $10-12$ undesirable effects that currently apply to the problem at hand. A total of 18 undesirable effects (UDEs) were identified from the current mode of Transportation, Storage and Sale of Fresh Fruits \& Vegetables in Nigeria as listed below: 
Table 1: List of Undesirable Effects

\begin{tabular}{|c|c|}
\hline $\begin{array}{l}\text { UDE } \\
\text { Number }\end{array}$ & Undesirable Effect \\
\hline UDE \# 1 & The availability of produce is inconsistent from season to season. \\
\hline UDE \# 2 & Income and profits to the sellers will be reduced. \\
\hline UDE \# 3 & Traders do not have the produce to sell. \\
\hline UDE \# 4 & There will be an adverse impact on economy. \\
\hline UDE \# 5 & $\begin{array}{l}\text { Consumers have to settle for different varieties or specie they are not used to and which } \\
\text { in most cases are sub-standard produce. }\end{array}$ \\
\hline UDE \# 6 & Importation of produce, which otherwise is readily available locally can be used in its \\
\hline UDE \# 7 & Traders have limited financial capacity to purchase the produce \\
\hline UDE \# 8 & $\begin{array}{l}\text { Graduates of Agricultural Sciences and relevant courses prefer to take more lucrative } \\
\text { white collar iobs. }\end{array}$ \\
\hline UDE \# 9 & Lack of education on the proper handling of produce. \\
\hline UDE \# 10 & Wastage of produce can exist. \\
\hline UDE \# 11 & Experienced / educated people are not involved in the marketing system of the industry \\
\hline UDE \# 12 & $\begin{array}{l}\text { People who study agricultural Sciences and relevant courses hardly have enough } \\
\text { financial capacity to start their own business }\end{array}$ \\
\hline UDE \# 13 & A loss of income can occur \\
\hline UDE \# 14 & There can be significant post-harvest losses \\
\hline UDE \# 15 & Lack of exposure to modern farming technology by producers, wholesaler, retailers in the \\
\hline UDE \# 16 & Outdated/inadequate propagation, transportation, processing and preservation \\
\hline UDE \# 17 & Period of excess produce exists \\
\hline UDE \# 18 & There can be a scarcity of produce \\
\hline
\end{tabular}

\section{The Current Reality Tree}

After organizing the Undesirable Effects in an effect-cause-effect relationship analysis, a tree took shape that identified UDE \#16, "Outdated/inadequate propagation, transportation, processing and preservation techniques are used." as the core problem. The core problem will be located at the bottom of the tree with all other UDEs leading from the core problem. The Current Reality Tree is read from the bottom starting with the core problem and progressing upward through the tree using if ... then statements in a logical order.

The tree reads as follows (See Figure 1 Current Reality Tree):

- If outdated/inadequate propagation, transportation, processing and preservation techniques are used then the availability of produce is inconsistent from season to season. If the availability of produce is inconsistent from season to season and there are seasons of abundant produce then Period of excess produce exist. If period of excess produce exist and there is lack of exposure to modern farming technology by producers, wholesaler and retailers in the industry and outdated/inadequate propagation, transportation, processing and preservation techniques are used, then there can be significant post-harvest losses. If there can be significant post-harvest losses and wastage of produce can exist and the produce could have been turned into income, then a loss of income can occur. If a loss of income can occur, then there will be an adverse impact on economy.

- If Outdated/inadequate propagation, transportation, processing and preservation techniques are used, then the availability of produce is inconsistent from season to season. If the availability of produce is inconsistent from season to season and there are season of produce 
shortage then, there can be a scarcity of produce. If there can be a scarcity of produce, then consumers have to settle for different varieties or specie they are not used to which in most cases are substandard. If consumers have to settle for different varieties or species they are not used, to which in most cases are substandard then, consumers are dissatisfied.

- If outdated/inadequate propagation, transportation, processing and preservation techniques are used, then the availability of produce is inconsistent from season to season. If the availability of produce is inconsistent from season to season and there are season of produce shortage then there can be a scarcity of produce. If there can be a scarcity of produce, and scarcity of produce exists, then traders do not have the produce to sell. If traders do not have the produce to sell and Produce is readily available from importation, then Importation of produce, which otherwise is readily available locally can be used in its place. If Importation of produce occurs and importation of the produce causes the price to increase, then the price of the imported produce can increase. If the price of the imported produce can increase, then consumers have to buy produce at exorbitant prices. If consumers have to buy produce at exorbitant prices then Consumers are dissatisfied.

- If Graduates of Agricultural Sciences and relevant courses prefer to take more lucrative white collar jobs and People who study agricultural Sciences and relevant courses hardly have enough financial capacity to start their own business, then, experienced / educated people are not involved in the marketing system of the industry. If experienced / educated people are not involved in the marketing system of the industry and most traders in developing countries are uneducated and small scale then, traders have limited financial capacity to purchase the produce.
If traders have limited financial capacity to purchase the produce and the price of the imported produce can increase, then traders can only afford limited quantity to sell. If traders can only afford limited quantity to sell, then the income and profits to the traders will be reduced. If the income and profits to the traders will be reduced, then there will be an adverse impact on economy.

- If Graduates of Agricultural Sciences and relevant courses prefer to take more lucrative white collar jobs and People who study agricultural Sciences and relevant courses hardly have enough financial capacity to start their own business, then, experienced / educated people are not involved in the marketing system of the industry. If experienced / educated people are not involved in the marketing system of the industry, then there is lack of education on the proper handling of produce. If there is lack of education on the proper handling of produce then damage to the produce can occur. If damage to the produce can occur, then wastage of produce can exist. If the wastage of produce can exist, then a loss of income can occur. If a loss of income can occur, then there will be an adverse impact on economy.

- If Graduates of Agricultural Sciences and relevant courses prefer to take more lucrative white collar jobs and People who study agricultural Sciences and relevant courses hardly have enough financial capacity to start their own business, then, experienced / educated people are not involved in the marketing system of the industry. If experienced / educated people are not involved in the marketing system of the industry and farmers are used to the outdated farming techniques, then, there is lack of exposure to modern farming technology by propagation, transportation, processing and preservation techniques are used, then there can be significant postharvest losses. If there can be significant post- 
7 Journal of African Research in Business \& Technology

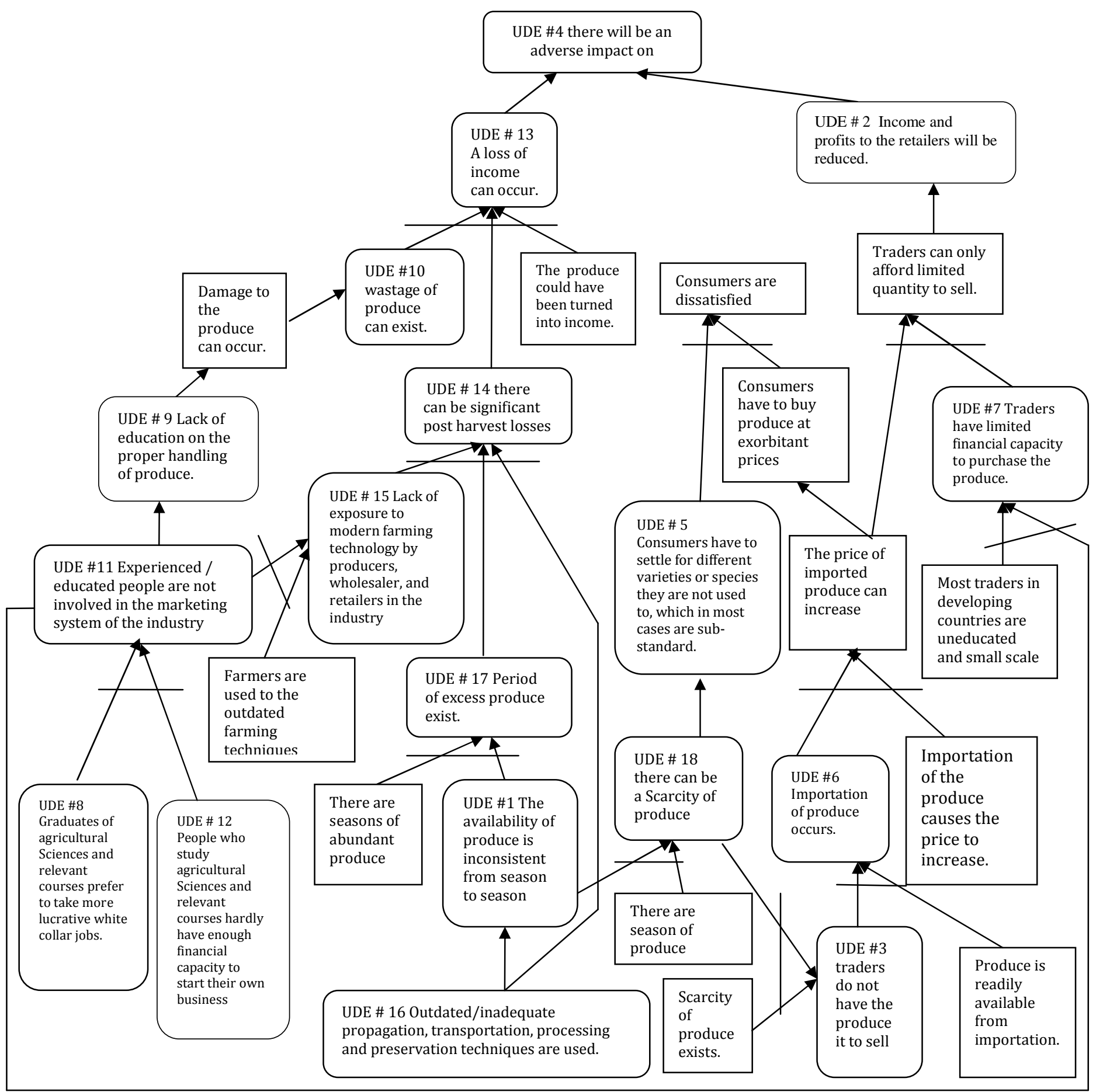

Figure 1: Current Reality Tree 
harvest losses, and the produce could have been turned into income and wastage of produce can exist, then a loss of income can occur. If a loss of income can occur, then there will be an adverse impact on economy.

\section{What to Change to?}

Once the Current Reality Tree is formed a conflict emerges and pulls the situation in two directions. The most common way of managing conflict is to compromise in some way. However, if compromise were a true solution for the problem, the conflict would have been eliminated a long time ago. Therefore the tendency to look for a compromise to handle the situation should be overcome and the true core problem should be eliminated.

Goldratt [1992-a] stated that since a vacuum does not exist, eliminating the core problem means creating a new reality, in which the opposite of the core problem exists. To eliminate the core problem, a tool known as the Evaporating Cloud (EC) should be used. An EC, according to Goldratt [1993] lets a person precisely present the conflict facilitating the core problem and then helps find $a$ solution by challenging the assumptions causing the conflict. The EC starts with an objective that is the opposite of the core problem. From the objective, the requirements (minimum of two) are listed. Each requirement will have at least one prerequisite. It is the prerequisite that depicts the conflict. All of the requirements and prerequisites are based on assumptions that have been ingrained into our minds over time. It is these assumptions that keep us in the conflicted environment. This is the first step in freeing ourselves from the binding controversy.

\section{Evaporating Cloud}

Goldratt contends that compromising does not solve the core problem though shortterm success may be realized. He suggests using the Evaporating Cloud to search for real solutions that will break the conflict that bring about a win-win solution for everyone. The core problem is "Outdated/inadequate propagation, transportation, processing and preservation techniques are used." so the objective of the EC will be "Achieve proper propagation, transportation, and processing and preservation techniques in the industry." Next, we must list a minimum of two requirements. Each requirement will have at least one prerequisite. It is the prerequisites that depict the conflict. The zigzag arrow between the two prerequisites represents the conflict. To read the EC one would use "in order to ...we (they) must" syntax.

The Evaporating Cloud reads as follows (See Figure 2 - Evaporating Cloud):

- In order to achieve proper propagation, transportation, processing and preservation techniques in the industry, People in the industry must be willing to become educated to adopt and implement new techniques and at the same time, the people in agricultural extension agencies must be willing to educate the people in the industry to adopt and implement new techniques.

- In order for People in the industry to be willing to become educated to adopt and implement new techniques, the people in industry must be in charge and the people in the industry must put their funds into the act of actual production and selling of their products.

- In order for the people in agricultural extension agencies to be willing to educate the people in the industry to adopt and implement new techniques the people in education must be in charge and the people in the industry must put their funds into education to improve the actual production and selling of their products. 


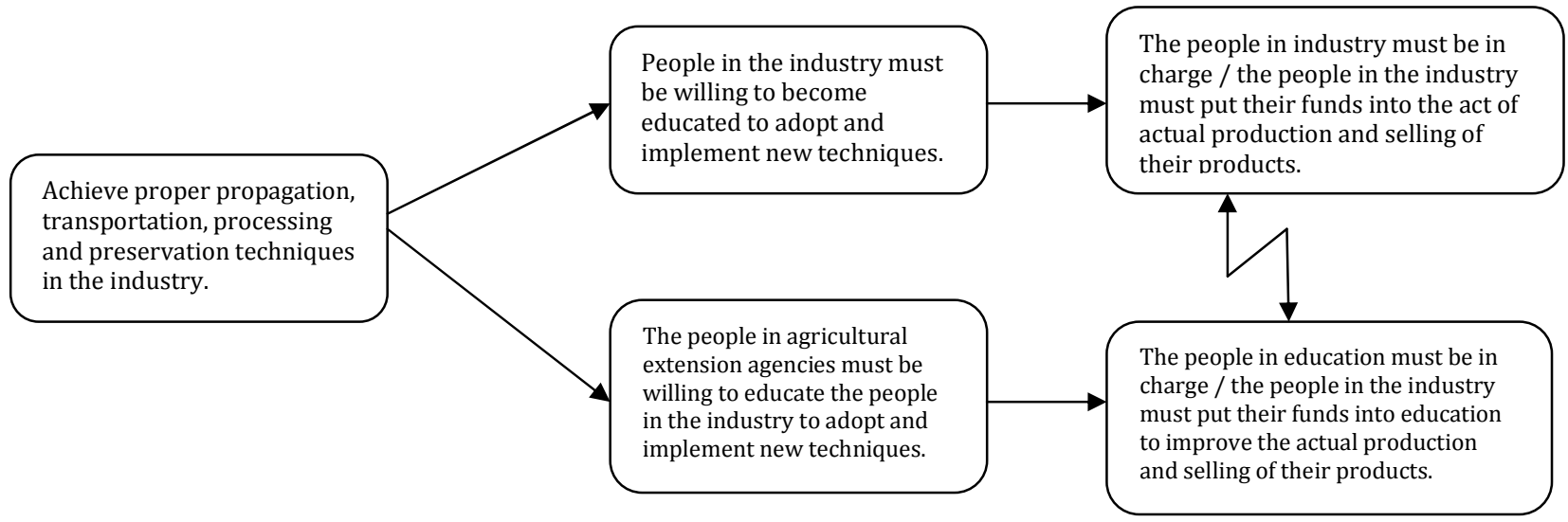

Figure 2 - Evaporating Cloud (EC)

The injections in this instance are:

1. We make the industry more attractive to educated individuals, through provision of adequate training, financial aid or loans from Government or financial institutions.
2. Make the proper propagation, transportation, processing and preservation techniques and equipment readily available through Government loans or grants.
Achieve proper propagation, transportation, processing and preservation techniques in the industry.
People in the industry must be willing to become educated to adopt and implement new techniques.

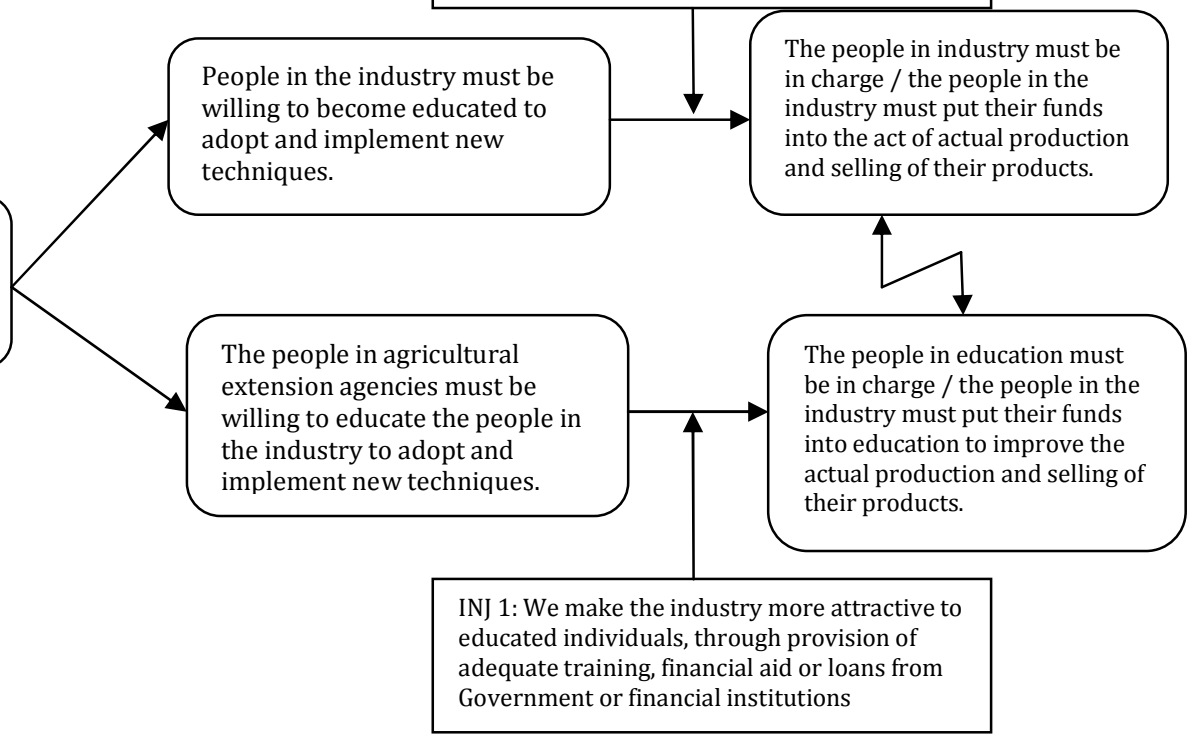

INJ 2: Make the proper propagation techniques and equipment readily available through Government loans or grants

Figure 3 - Evaporating Cloud with Injections (EC w/injections)

This tool will logically show that once the injections are implemented, the desirable effects can be accomplished. When the EC is broken, the FRT is built using the injections from the EC. The injections are connected with the cause-and-effect logic and "clarities" 
and "insufficiencies" may be used where additional information is required. This process tests the solution and is enhanced by criticism and negative comments. If criticisms, negative comments and UDEs can be overcome by the proposed solution then this provides proof of the solution and leads to the next step in the process. This process taps into the natural tendencies of criticism and negativity.

\section{How to Cause the Change}

Next consider whether the injections will direct desirable effects. An injection allows for an acceptable resolution to one side of the conflict. With the injections and the logical based common sense cause and effect relationships, the desired effects can be connected and the future outcome developed. This technique is called building the Future Reality Tree (FRT). The FRT according to Goldratt [1993] is the thinking process that enables a person to construct a solution that, when implemented, replaces the existing undesirable effects by desirable effects without creating devastating new ones. Goldratt [1992-b] goes on to add, the analytical method of the FRT is used to construct and scrutinize such a solution.

This tool will logically show that once the injections are implemented, the desirable effects can be accomplished. When the EC is broken, the FRT is built using the injections from the EC. The injections are connected with the Effect-Cause-Effect logic and clarities and insufficiencies are used where additional information is required. This process tests the solution and is enhanced by criticism and negative comments. If criticisms, negative comments and UDEs can be overcome by the proposed solution then this provides proof of the solution and leads to the next step in the process. This process taps into the natural tendencies of criticism and negativity.

\section{Future Reality Tree}

A FRT was then constructed in an effort to ensure that all of the UDEs would be eliminated using the resolution identified in the EC. The FRT is essentially the same as the CRT; however the injection(s) identified in the EC are placed into the tree to create a vision of the "future reality." The FRT is read from the bottom up using if...then statements in a logical format just as the CRT.

The tree reads as follows (See Figure 4 Future Reality Tree):

- If ewe make the industry more attractive to educated individuals through provision of adequat training, financial aid or loans from Government or financial institutions, then Graduates of agricultural Sciences and relevant courses would be interested in working in the industry and people who study Agricultural Sciences and relevant courses would have the financial capacity to start their own business. If Graduates of agricultural Sciences and relevant courses are interested in working in the industry and people who study Agricultural Sciences and relevant courses have the financial capacity to start their own business, then experienced and educated people would get involved in the marketing system of the industry. If experienced and educated people would get involved in the marketing system of the industry, then there would be adequate knowledge on the proper handling of produce. If there would be adequate knowledge on the proper handling of produce, then there would be less damage to the produce. If there would be less damage to the produce then, wastage of produce would be vastly reduced. If the wastage of produce would be vastly reduced and post-harvest losses are significantly reduced and more produce would be available for sale then, more income would be generated. If more income would be generated, then there would be a positive impact on economy. 
- If we make the industry more attractive to educated individuals, through provision of adequate training, financial aid or loans from Government or financial institutions, then Graduates of Agricultural Sciences and relevant courses are would be interested in working in the industry and people who study Agricultural Sciences and relevant courses would have the financial capacity to start their own business. If Graduates of Agricultural Sciences and relevant courses would be interested in working in the industry and people who study.

- Agricultural Sciences and relevant courses would have the financial capacity to start their own business, then experienced and educated people would get involved in the marketing system of the industry. If experienced and educated people would get involved in the marketing system of the industry and modern techniques are being used, then Producers, wholesaler, retailers in the industry would be exposed to modern technology. If Producers, wholesaler, retailers in the industry would be exposed to modern technology and Period of consistent produce would exist and modern propagation, transportation, processing and preservation techniques would be used, then post-harvest losses would be significantly reduced. If postharvest losses are significantly reduced and more produce would be available for sale and turned into income and the wastage of produce would be vastly reduced, then more Income would be generated. If more Income would be generated then, there would be a Positive impact on the economy.

- If we make the proper propagation, transportation, processing and preservation techniques and equipment readily available through Government loans or grants then, modern propagation, transportation, processing and preservation techniques would be used. If modern propagation, transportation, processing and preservation techniques would be used, then, the availability of local produce would be more consistent from season to season. If the availability of local produce would be more consistent from season to season then Period of consistent produce would exist. If Period of consistent produce would exist and producers, wholesaler, retailers in the industry would be exposed to modern technology and modern propagation, transportation, processing and preservation techniques would be used, then Post-harvest losses would be significantly reduced. If Post-harvest losses would be significantly reduced and more produce would be available for sale and turned into income and the wastage of produce. 


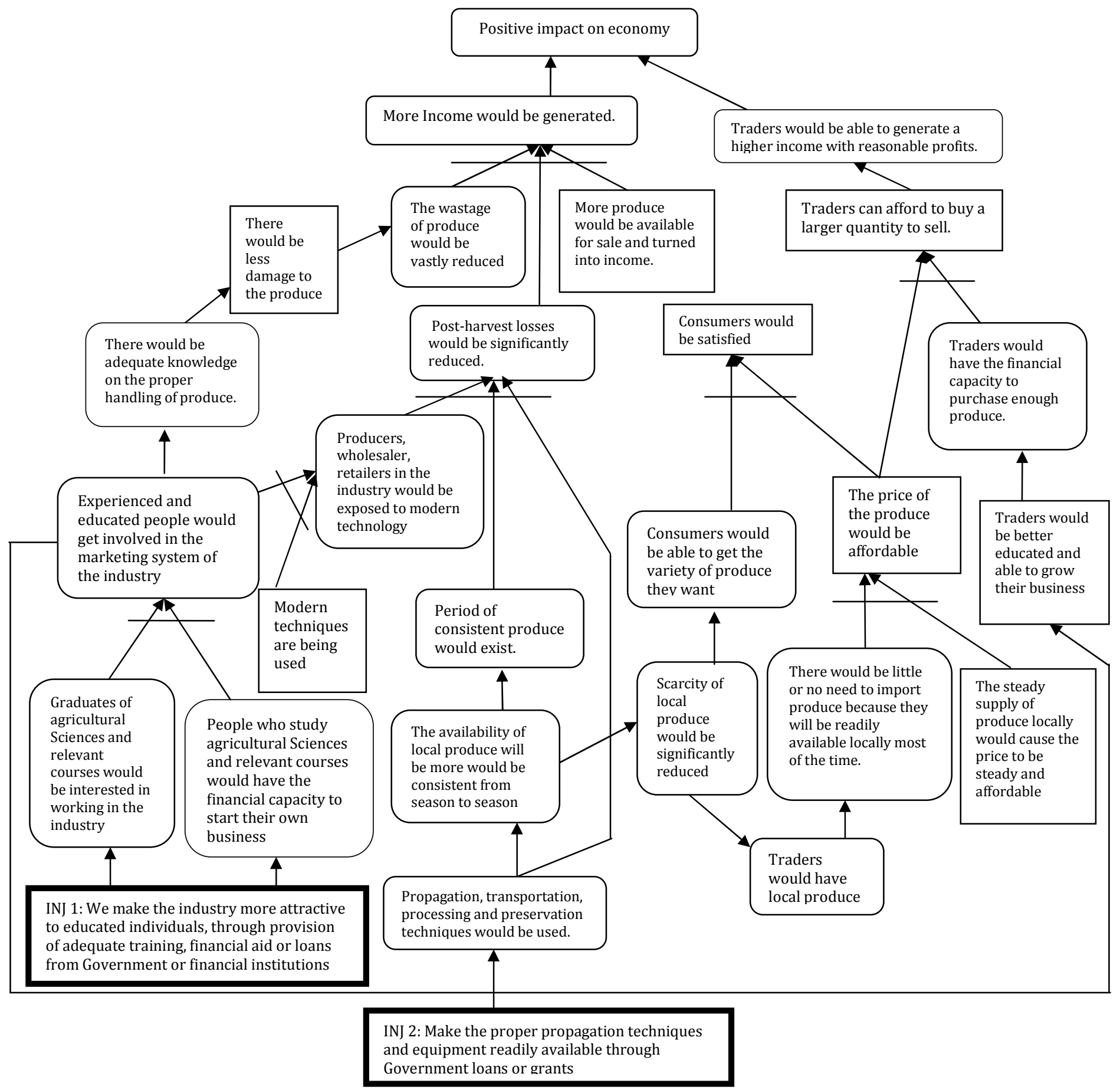

Figure 4: Future Reality Tree 
would be vastly reduced, then more income would be generated. If more income would be generated, then there would be positive impact on economy.

- If we make the proper propagation, transportation, processing and preservation techniques and equipment readily available through Government loans or grants then, modern propagation, transportation, processing and preservation techniques would be used. If modern propagation, transportation, processing and preservation techniques would be used, then, the availability of local produce would be more consistent from season to season. If the availability of local produce would be more consistent from season to season then, scarcity of local produce would be significantly reduced. If scarcity of local produce would be significantly reduced then consumers would be able to get the variety of produce they want. If consumers would be able to get the variety of produce they want, then consumers would be satisfied.

- If we make the proper propagation, transportation, processing and preservation techniques and equipment readily available through Government loans or grants then, modern propagation, transportation, processing and preservation techniques would be used. If modern propagation, transportation, processing and preservation techniques would be used, then, the availability of local produce would be more consistent from season to season. If the availability of local produce would be more consistent from season to season then, scarcity of local produce would be significantly reduced. If scarcity of local produce would be significantly reduced then traders would have local produce to sell. If traders would have local produce to sell, then there would be little or no need to import produce because they will be readily available locally most of the time. If there would be little or no need to import produce because they will be readily available locally most of the time and the steady supply of produce locally would cause the price to be steady and affordable then, the price of the produce would be affordable. If the price of the produce is affordable and consumers are able to get the variety of produce they want, then consumers are satisfied.

- If we make the proper propagation, transportation, processing and preservation techniques and equipment readily available through Government loans or grants then, modern propagation, transportation, processing and preservation techniques would be used. If modern propagation, transportation, processing and preservation techniques would be used, then, the availability of local produce would be more consistent from season to season. If the availability of local produce would be more consistent from season to season then, scarcity of local produce would be significantly reduced. If scarcity of local produce would be significantly reduced then traders would have local produce to sell. If traders would have local produce to sell, then there would be little or no need to import produce because they will be readily available locally most of the time. If there would be little or no need to import produce because they will be readily available locally most of the time and the steady supply of produce locally would cause the price to be steady and affordable then, the price of the produce would be affordable. If the price of the produce is affordable. If the price of the produce would be affordable and retailers would have the financial capacity to purchase enough produce then, retailers can afford to buy a larger quantity to sell. If retailers can afford to buy a larger quantity to sell, then retailers would be able to generate a higher income with reasonable profits. If retailers would be able to generate a higher income with reasonable profits then there is positive impact on economy. 
- If we make the industry more attractive to educated individuals through provision of adequate training, financial aid or loans from Government or financial institutions, then Graduates of agricultural Sciences and relevant courses would be interested in working in the industry and people who study Agricultural Sciences and relevant courses would have the financial capacity to start their own business. If Graduates of agricultural Sciences and relevant courses are interested in working in the industry and people who study Agricultural Sciences and relevant courses have the financial capacity to start their own business, then experienced and educated people would get involved in the marketing system of the industry. If experienced and educated people would get involved in the marketing system of the industry, then then traders would be better educated and are able to grow their business. If traders would be better educated and able to grow their business, then traders would have the financial capacity to purchase enough produce. If traders would have the financial capacity to purchase enough produce and the price of the produce would be affordable, then traders can afford to buy a larger quantity to sell. If retailers can afford to buy a larger quantity to sell, then traders would be able to generate a higher income with reasonable profits. If traders would be able to generate a higher income with reasonable profits then there would be a positive impact on economy.

\section{Conclusion}

If steps can be taken to implement the two injections that were used to break the evaporative cloud, then the prevailing problems in the fruits and vegetables industry can be easily resolved i.e.:

i. Make the industry more attractive to educated individuals, through provision of adequate training, financial aid or loans from Government or financial institutions and; ii. Provide Government loans or grants and make it easily accessible to the people in the industry so that people in the industry can afford to buy modern equipment and implement modern propagation, transportation, processing and preservation techniques.

These actions, if implemented, would effectively lead to a great improvement in the fruit and vegetable sector. The produce will be better managed, and post-harvest losses, scarcity, wastage etc will be significantly reduced. This will also lead to increased income to the farmers; subsequently make the farming profession more attractive to young and educated people who are thinking of starting their own business, because the cultivation and production of produce will become more viable and would ultimately be beneficial to Nigeria's economy.

\section{Summary}

This procedure, although somewhat different from the normal methods of analysis, is so practical, that it can be applied to any problem anywhere and anytime. According to Goldratt [1992-b], you start with an effect in reality, and then hypothesize a plausible cause for the existence of that effect. Since the aim is to reveal the underlying causes that govern the entire subject, try to validate the hypothesis by predicting what else this hypothesis must cause. Once such predictions are found, concentrate efforts to verify whether or not each prediction holds water by asking questions. If it turns out that one of the predictions doesn't hold up, find another hypothesis. If all of them hold up, continue until the entire subject is understood through the bonds of cause and effect.

Bob Fox [1989], President of the Goldratt Institute, states: I do not believe any longer that the challenge is the technology of what to do. That has been well developed - maybe not disseminated very well yet, but developed. The issue is the resistance to change once we know what to do, and I 
believe there is a solution to that. This method of problem solving requires ability that everyone has and stems from the systematic methods and thinking processes. It provides you with the framework necessary to direct these efforts and to verbalize your intuition to gain a better understanding of managements "intestinal sensations."

Everyone has self-doubt. This self-doubt makes it very difficult to use the scientific method of analysis. Goldratt [1992-b] reveals, "the scientific method involves reaching into the unknown; speculating a cause and determining predicted effects probably requires an awkward personality that thrives on the unknown". But we are dealing with the known, with current reality. There must be an equivalent method, a thinking process that facilitates building a current reality tree within the known, and we can effectively use it on any subject that we have intuition for and care about.

This cause and effect approach is used in many areas of Science and Mathematics. The demonstrated thinking process is what managers need the most. To carry out a successful process of ongoing improvement there is nothing more important than the ability to answer: "What to change?", "What to change to?", and "How to cause the change?" The results are well worth the required investments.

\section{References}

Adeniyi, M. O. (1977). 'Status of Plant Protection in the Operation Feed the Nation Programmes, Presidential Address Delivered at the 7th Annual Conference of the Institute of Agriculture Research and Technology (IAR\&T),' Moore Plantation in Ibadan Page 10-17.

Agboola, S. D. (1980). 'The Role of the Nigerian Stored Products Research Institute in Nigeria March towards Self-Sufficiency in Food,' NSPRI Occasional Paper Series No. 117 Page 25-29.
Erinle, I. D. (1988). Present Status and Prospects for Increased Production of Tomato and Pepper in Northern Nigeria. Proc. Int. Symp. Integrated Manage. Practices. AVRDC, Tainan, Taiwan.

Food and Agriculture Organization (FAO) (1989). Prevention of Post-Harvest Food Losses: Fruits, Vegetables and Root Crops. Training Manual Rome (Italy) http://www.fao.org/docrep/T0073E/T0073 E00.htm

Fox, R. E. (1988). 'The Constraint Theory,' Internal working paper, Avraham Y. Goldratt Institute, New Haven Connecticut.

Goldratt, E. M. (1992-a). 'An Introduction to Theory of Constraints: The Production Approach,' Avraham Y. Goldratt Institute.

Goldratt, E. M. (1992-b). 'An Introduction to Theory of Constraints: THE GOAL APPROACH,' Avraham Y. Goldratt Institute.

Goldratt, E. M. (1993). 'What Is the Theory of Constraints?,' APICS the Performance Advantage, June 1993.

Goldratt, E. M. (1994). It's Not Luck. Massachusetts: North River Press.

Hall, F. W. (1968). 'Prevention of Waste of Agricultural Produce During Handling, Storage and Transportation,' Tropical Stored Institute pp. 15 - 23.

Idah, P. A., Ajisegiri, E. S. A. \& Yisa, M. G. (2007). "Fruits and Vegetables Handling and Transportation in Nigeria," Australian Journal of Technology 10(3) $175-183$.

Jones, C. S., Holt, J. E. \& Schoorl, D. (1991). "A Model to Predict Damage to Horticultural Produce During Transport," J. Agric. Engin. Res. 50: 259-72.

Okhuoya, J. A. (1995). 'Controlling PostHarvest Losses in Tomatoes and Pepper,' J. Trop Postharv 2: $136-42$. 
Olayemi, F. F., Adegbola, J. A., Bamishaiye, E. I. \& Daura, A. M. (2010). "Assessment of PostHarvest Challenges of Small Scale Farm Holders of Tomatoes, Bell and Hot Pepper in Some Local Government Areas of Kano State, Nigeria," Bayero Journal of Pure and Applied Sciences, 3(2): $39-42$.

Oyeniran, J. O. (1988). 'Report of the Nationally Coordinated Research Project on Fruits and Vegetables in Nigeria,' Proc. Nat. Workshop on Improved Packaging and Storage Systems for Fruits and Vegetables in Nigeria. Ilorin, Nigeria.

The World Fact Book.:Nigeria. Retrieved from

https://www.cia.gov/library/publications/t he-world-factbook/geos/ni.html 